Nigerian Journal of Physiological Sciences 23 (1-2): 27-30 @Physiological Society of Nigeria, 2008

Available online/abstracted at http://www.bioline.org.br/np; www.ajol.info/journals.nips; www.cas.org

\title{
EFFECTS OF PHOTOPERIOD ON TESTICULAR FUNCTIONS IN MALE SPRAGUE-DAWLEY RATS
}

\section{A. OLAYAKI*, A. O. SOLADOYE, T. M. SALMAN AND B. JORAIAH}

*Department of Physiology, Faculty of Basic Medical Science, College of Health Sciences, University of Ilorin, Ilorin, Kwara State, Nigeria. E-mail:luqmanolayaki@yahoo.com Tel: +234 8033814880

Summary: Variation in reproductive status in response to photoperiods has been observed in laboratory rats. We investigated the effects of photoperiod on testicular activity in Sprague-Dawley rats (Rattus norvigicus) maintained in experimental photoperiodic condition. Twenty four adult male rats weighing $170 \pm 10 \mathrm{~g}$ were conditioned to different lighting conditions of Light/Dark (LD) Cycle for 6 weeks. Group 1, Control group (LD12:12, light on from 07:00hr to 19:00hr). Group 2, Short Photoperiod group (LD 8:16hr, light on from 09:00hr to 17:00hr). Group 3, Long Photoperiod group (LD 16:8hr, light on from 05:00hr to 21:00hr). A significant influence of different lighting conditions on the testicular parameters was observed. Short photoperiod showed a suppressing effect $(\mathrm{P}<0.001)$ on testicular weight, sperm motility sperm viability and sperm counts, while long photoperiod had an inducing, though insignificant, effect on the measured parameters. The results confirmed that SpragueDawley rats are photoresponsive and changes in the photoperiod could influence their reproductive functions.

Key Words: Photoperiod, Sperm motility, Sperm viability, Sperm counts, Testicular weight.

\section{Introduction}

In some mammals, reproduction follows a seasonal pattern that is often under photoperiodic control. Such patterns have evolved so that animals give birth during period when environmental conditions are favourable, maximizing the chances that the young will survive. One of the most reliable seasonal predictors appears to be photoperiod (Bronson, 1989; Boissin and Canguilhem, 1998). Depending on the species, photoperiod may either trigger onset of the reproductive period (a stimulating effect), or initiate gonadal regression (an inhibitory effect). In long-day breeding species, the seasonal increase ij sexual activity occurs when the amount of daylight increases, and in short-day breeding species, the reproductive season is triggered by the shortening of day length, (Ben Saad and Maurel, 2002). Melatonin, a 5-methoxyindole synthesized by the pineal gland, plays a major role in photoperiod-mediated control of reproduction in mammals with seasonal breeding patterns determined by day length in their natural environment, and the circadian pattern of melatonin secretion constitute an endocrine message that provides information regarding the photoperiod (Reiter, 1986; Reiter, 1991; Arendt, 1995; 1995; Goldman, 1999).

Variation in reproductive status and body mass in response to short photoperiod has been observed in laboratory rats (Leadem, 1988; Heideman and Sylvester, 1997). Studies have shown that the Fischer 344 (F344) and Brown Norway (BN) inbred rat strains exhibit robust obligate photoresponsiveness, repressing reproduction, food intake, and somatic growth in the absence of light (Leadem, 1988). Or short photoperiods (Heideman and Sylvester, 1997; Lorincz et al., 2001; Shoemaker and Heideman, 2002). In contrast, other strains of laboratory rats have not been considered functionally photoresponsive because unmanipulated rats of these strains show little or no marked differences in body mass, gonad size, or food intake in response to short photoperiod (Nelson et al, 1994). However, photoresponsiveness in rats does not fall neatly into two phenotypes, for example in some of the rat strains considered nonphotoperiodic, including Wistar and Sprague-Dawley outbred strains, photoperiodic response can be unmasked by treatments such as administration of androgen (Wallen and Turek, 1981; Wallen et al., 1987). In view of the variation in the response to changes in the photoperiod among rat strains, further investigation into this phenomenon becomes worthwhile.

The present study was therefore designed to investigate the effects of photoperiod on testicular functions in SpragueDawley rats. In this study, we investigated young males of Sprague-Dawley rat. This strain was chosen because it is the most commonly used type of rats in our laboratory. The objectives of the study were to test whether photoperiodic responses might be 
widespread in this strain of rats and to assess the magnitude of any photoperiodic responses on reproductive functions.

\section{Materials and Methods}

Twenty four Sprague-Dawley rats were obtained from Animal Breeding Unit of the Department of Biochemistry, University of Ilorin, Nigeria. The rats weighed $170 \pm 10 \mathrm{~g}$ and were conditioned to different lighting conditions for 6 weeks. All animals were housed in plastic cages with stainless steel mesh cover under standard laboratory conditions in photoperiod-control chambers. Lighting in photoperiod chambers was provided by 6-watt fluorescent tubes at illuminance of 100-250 lux, $5 \mathrm{~cm}$ above each cage. The experiment was conducted during the raining season. Rats pellet and tap water were provided ad libitum. All animals received humane care. The animals were divided into 3 groups of 6 animals per group, with groups I, II and III subjected to photoperiodic conditions of light/dark cycle of $12: 12 \mathrm{~h}, 8: 16 \mathrm{~h}$, and $16: 8 \mathrm{~h}$ respectively, as shown in Table 1 . At the end of the experiment, (6 weeks), the rats were anaesthesized with urethane $(5 \mathrm{mg} / \mathrm{kg})$, body weight was measured, both testes were excised, and wet weight was recorded.

\section{Sperm Motility, Viability and Counts}

The caudal epididymis was immediately dissected. An incision (about $1 \mathrm{~mm}$ ) was then made in the caudal epididymis. A drop of sperm fluid was squeezed onto the microscope slide and 2 drops of normal saline were added to mobilize the sperm cells. Epididymal sperm motility was then assessed by calculating motile spermatozoa per unit area and was expressed in percentage. Epididymal sperm counts were done by first homogenizing the epididymis in $5 \mathrm{ml}$ of normal saline. The counting was then done using the counting chamber in the haemocytometer (Adeeko and Dada, 1998). The sperm viability was also determined using Eosin/Nigrosin stain as earlier described (Raji et al, 2003).
Statistical Analysis Data were expressed as mean \pm SEM. Statistical significance was determined suing the student's t-test. $\mathrm{P}<0.05$ ) was considered significant.

Table 1: Animal Groups (Control and Experimental), Light/Dark Cycle, and Photoperiod

\begin{tabular}{|c|c|c|c|}
\hline Groups & I & II & III \\
\hline Study & Control & $\begin{array}{c}\text { Experiment } \\
\text { al }\end{array}$ & $\begin{array}{c}\text { Experiment } \\
\text { al }\end{array}$ \\
\hline $\begin{array}{c}\text { Light/ } \\
\text { Dark } \\
\text { Cycle } \\
\text { (hrs) }\end{array}$ & $12: 12 \mathrm{~h}$ & $8.16 \mathrm{~h}$ & $16: \mathrm{h}$ \\
\hline Time & $7.00-$ & $9.00-17.00 \mathrm{~h}$ & $5.00-21.00 \mathrm{~h}$ \\
\hline $\begin{array}{c}\text { Photo } \\
\text { period }\end{array}$ & Natural & Short & Long \\
\hline
\end{tabular}

\section{Results}

The results (Table 2), showed that there was a significant decrease $(\mathrm{P}<0.005)$ in testicular-body-weight ratio from $0.01 \pm$ $0.001 \mathrm{~g}$ to $0.004 \pm 0.001 \mathrm{~g}$ in short photoperiod (SP) group compared to control, about $60 \%$ reduction. Long photoperiod (LP) did not affect the testicular-body weight ratio.

SP significantly reduced sperm motility $(\mathrm{P}<0.005)$ from $72.60 \pm 8.44 \%$ in the control group to $29.00 \pm 5.42 \%$ in the SP group. LP increased sperm motility from $72.60 \pm 8.44 \%$ in the control group to $74.00 \pm 6.52 \%$ in LP group, but this was not statistically significant $(\mathrm{P}=0.72)$. SP showed a significant effect on sperm viability, which was reduced from 57.00 $\pm 11.51 \%$ in the control group to $23.00 \pm$ $3.42 \%$ in the SP group $(\mathrm{P}<0.005)$, while it was insignificantly $(\mathrm{P}<0.42)$ increased to $64.00 \pm$ $14.36 \%$ in LP group.

Moreover, SP significantly reduced sperm counts from $41.60 \pm 7.89 \times 10^{6} / \mathrm{ml}$ in the control group, to $17.70 \pm 3.56 \times 10^{6} / \mathrm{ml}$ in the SP group, $\quad(\mathrm{P}<0.001)$ while LP slightly increased the sperm count to $44.60 \pm 9.86 \mathrm{x}$ $10 \%$ ml, but this was not statistically significant $(\mathrm{P}=0.24)$.

Table 2: Effect of Photoperiod on testicular Weight, Sperm Motility, Viability, and Count in Control, $S P$, and $L P$.

\begin{tabular}{|c|c|c|c|c|}
\hline Groups & $\begin{array}{l}\text { Left \& Right } \\
\text { testes/Body } \\
\text { Weight (g) }\end{array}$ & $\begin{array}{l}\text { Sperm Motility } \\
(\%)\end{array}$ & $\begin{array}{l}\text { Sperm Viability } \\
(\%)\end{array}$ & $\begin{array}{l}\text { Sperm Count } \\
\left(10^{6} / \mathrm{mm}\right)\end{array}$ \\
\hline $\begin{array}{l}\text { Control } \\
\text { (12D:12L) }\end{array}$ & $0.01 \pm 0.001$ & $72.60 \pm 8.44$ & $57.00 \pm 11.51$ & $41.60 \pm 7.89$ \\
\hline $\begin{array}{l}\text { SP (16D:8L) } \\
\text { LP (8D:16L) }\end{array}$ & $\begin{array}{l}0.004 \pm 0.001^{\mathrm{a}} \\
0.01 \pm 0.001\end{array}$ & $\begin{array}{l}29.00 \pm 5.42^{\mathrm{a}} \\
74.00 \pm 6.52\end{array}$ & $\begin{array}{l}23.00 \pm 3.42^{\mathrm{a}} \\
64.00 \pm 14.36\end{array}$ & $\begin{array}{l}17.70 \pm 3.56^{\mathrm{a}} \\
44.60 \pm 9.86\end{array}$ \\
\hline
\end{tabular}




\section{Discussion}

The results of this study show that male Sprague-Dawley rats are photoresponsive. The rats showed significantly lower reproductive organ masses, sperm motility, viability, and counts following exposure to short photoperiod (SP). There was also insignificant increase in sperm motility, viability, and counts, but not testicular-body weight ratio on exposure to long photoperiod (LP). Previous work on young male F344 and BN rats indicated that reproductive and body masses were reduced by SP (Heideman and Sylvester, 1997; Lorincz et al., 2001). SP has also been observed to have an inducing effect on male reproductive parameters in Zembra Island wild rabbits (Oryctolagus cuniculus) (Ben Saad and Maurel, 2002).

Earlier studies on wister and SpragueDawley rats showed that they were nonphotoperiodic and responded to photoperiod manipulation only after administration of androgen (Sorrentino et al, 1971; Wallen and Turek, 1981; Wallen et al, 1987) but the present study has shown that in the absence of any hormonal manipulation, photoperiod has significant effects on the measured reproductive parameters in the Sprague-Dawley rats. Exposure of hamsters to short photoperiods inhibits their reproductive system until there is testicular involution in males and anoestrous in females (Hoffman, 1973; Lerchl and Nieschlag, 1992). Pinealectomy, however, prevents gonadal regression in hamsters exposed to a shot photoperiod (Hoffman, 1979), implicating melatonin as the hormone responsible for the effects of photoperiod on reproductive parameters. Melatonin administration in hamsters mimics all the effects of short photoperiod on reproduction (Duncan et al, 1990; Buchanan and Yellon, 1991; Badra and Goldman, 1992; Pevet, 1993). The observed suppression of male reproductive parameters in SP group in our study could be due to actions of melatonin, which is known to be secreted at a very high rate during darkness due to 30-to 70fold increase in activity of $\mathrm{N}$-acetyltransferase, the enzyme that catalyses the penultimate step in the biosynthesis of melatonin (Ebadi, 1984).

Available evidence indicates that melatonin regulates the reproductive function in seasonal mammals by its inhibitory action at various levels of the hypothalamic-pituiatrygonadal axis. By acting on melatonin receptors $\left(\mathrm{MT}_{1}\right.$ and $\left.\mathrm{MT}_{2}\right)$ in the hypothalamus, anterior pituitary and reproductive organs, melatonin inhibits the reproductive system (Vanecek and Klein, 1992; Zemkova and Vanecek, 1997; Balik et al, 2004; Soares et al, 2003; Frungier et al, 2005). Melatonin is also known to reduce body weight by suppressing intraabdominal fat, plasma leptin, and plasma insulin in rats (Wolden-Hanson et al, 2000). Our study showed testicular-body weight ratio reduction in the SP group, suggesting that the effect of melatonin and possibly, photoperiod, is more pronounced on the gonadal weight than on the general body weight. Our observation of an insignificant increase in sperm parameters is consistent with earlier observation that light exposure and pinealectomy are associated with an enhancement in gonadal function (Kinson and Peat, 1971). We also observed an increase in sperm motility, viability and sperm count. But these increments were not statistical significant.

The present study confirmed that SpragueDawley rats are functionally photoresponsive and that in the absence of any hormonal manipulation, changes in the photoperiod could influence their reproductive functions.

\section{References}

Adeeko, A. O. and Dada, O. A. (1998). Chloroquine Reduces the Fertilizing Capacity of Epididymal Sperm in Rats . Afr. J. Med. Med. Sci. 27: 63-68.

Arendt, J. (1995). Melatonin and the mammalian pineal gland. London: Chapman and Hall.

Badura, L. L. and Goldman, B. D. (1992). Central sites mediating reproductive responses to melatonin in juvenile male Siberian hamsters. Brain. Res. 598-98-106.

Balik, a., Kretschmannova, K., Mazna, P., Svobodova, I., Zemkova, H. (2004). Melatonin action in neonatal gonadotrophs. Physiol. Res. 53 (Suppl. I), S153-S166.

Ben-Saad, M. M., and Maurel, D. L. (2002). Long-day inhibition of reproduction and circadian photogonadosensitivity in Zembra Island wild rabbits (Oryctolagus cuniculus). Biol. Reproduction. 66: 415-420.

Boissin, J. and Canguilhem, B. (1998). Les rhythmes du vivant, origine et controle des rhythmes biologiquess. Paris: Nathan CNRS

Bronson, F. H. (1989). Mammalian reproductive biology. Chicago: University of Chicago Press.

Buchannan, K. L. and Yellon, S. M. (1991). Delayed puberty inthemale Djugarian hamster: effect of short photoperiod or melatonin treatment on the Gn-RH neuronal system. Neuroendocrinology. 54:96-102.

Duncan, M. J., Fang, J. M., Dubocovich, M. L. (1990). Effects of melatonin agonists and antagonists on reproduction and body weight in the Siberian hamster. J. Pineal Res. 9:231-242. 
Ebadi, M. (1984). Regulation of the synthesis of melatonin and its significance to neuroendocrinology. In Reiter R. J., ed. The Pineal Gland, pp. 1-37. NY, Raven Press.

Frungier, M. B., Mayerhofer A., Zitta, K., Pignataro, O. P., Calandra, R. S., GonzalezCalvar, S. I. (2005). Direct effect of melatonin on Syrian hamster testes: melatonin subtype 1a receptors, inhibition of androgen production, and interaction with the local corticotrpin-releasing hormone system. Endocrinology. 146:1541-1552.

Goldman, B. D. (1991). Parameters of the circadian rhythm of pineal melatonin secretion affecting reproductive responses in Siberian hamsters. Steroids. 56:218-225.

Goldman, B. D. (1999). The circadian timing system and reproduction in mammals. Steroids. 64:679-685.

Heideman, P. D. and Sylvester, C. J. (1997). Reproductive photoresponsiveness in unmanipulated Fischer 344 laboratory rats. Biol. Reproduction. 57:134-138.

Hoffman, K. (1973). The influence of photoperiod and melatonin on testis size and body weight in the Djungarian hamster. $J$. Comp. Physiol. 85:267-282.

Hoffman, K. (1979). Photoperiod, pineal melatonin and reproduction in hamsters. Prog. Brain Res. 52:397-415.

Kinson, G. A. and Peat, F. (1971). The influences of illumination, melatonin, a dn pinealectomy on testicular functions in the rats. Life Sci. 10:259-269.

Leadem, C. A. (1988). Photoperiodic sensitivity of prepubertal female Fischar 344 rats. J. Pineal Gland. 5:63-70.

Lerchl, A. and Nieschlag, E. (1992). Interruption of nocturnal pineal melatonin sysnthesis in spontaneous recrudescent Djungarian hamsters (Phodopus sungorus). J. Pineal Res. 13:36-41.

Lorincz, a. M., Shoemaker, M. B., Heideman, P. D. (2001). Genetic variation in Phototoperiodism among naturally photoperiodic rat strains. Am. J. Physiol. Integr.Reg. Physiol. 281: R1817-R1824.

Nelson, R. J., Moffatt, C. A., Goldman, B. D. (1994). Reproductive and non-reproductive responsiveness to photoperiod in laboratory rats. J. Pineal Res. 17:123-131.

Pevet, P. (1993). Present and future of melatonin in human and animal reproduction functions. Contracept. Fertil. Sex 21:727-732.

Raji, Y., Udoh, U. S., Mewoyeka, O. O., Onoye, F. C., Bolarinwa, A. F. (2003). Implication of reproductive endocrine malfunction in male antifertility efficacy of
Azadirachta indica extract in rats. Afr. J. Med. Med. Sci. 32:159-165.

Reiter, R. J. (1986). Annual cycle of reproduction in mammals: adaptive mechanisms involving the photoperiod and the pineal gland. In: assenmacherl, Bioissin J., (eds.) Endocrine Regulations as adaptive Mechanisms to the Environment. Paris: Les Presses du CNRS, PG 161-170.

Reiter, R. J. (1991). Pineal melatonin: cell biology of its synthesis and of its physiological interactions. Endocrinol. Rev. 12:151-180.

Shoemaker, M. B. and Heideman, P. D. (2002). Reduced body mass. Food intake, and testis size in repsonse to short photoperiod in adult F344 rats BMC Physiology. 2: 11.

Soares, J. M., Masona, M. I., Erashin, C., Dubocovich, M. L., (2003). Functional receptors in rats' ovaries at various stages of the estrous cycle. J. Pharmacol. Exp. Ther. 306:694-702.

Sorrentino, S., Reiter, R. J., Schalch, D. S. (1971). Interactions of pineal gland, blinding and underfeeding on on reproductive organ size and radioimmunoassayable growth hormone. Neuroendocrinology. 7: 105-115.

Vanecek, J. and Klein, D. C. (1992). Melatonin inhibits gonadotropin-releasing hormoneinduced elevation of intracellular $\mathrm{Ca}^{2+}$ in neonatal in pituitary cells. Neuroendocrinology. 130:701-707.

Wallen, E. P., DeRosch, M. A., Thebert, A., Losee-Olson, S., turek, F. W. (1987). Photoperiodic response in the male laboratory rat. Biol. Reproduction. 37:22-27.

Wallen, E. P. and Turek, F. W. (1981). Photoperiodicity in the male albino laboratory rat. Nature. 289:402-404.

Wolden-Hanson, T., Mitton, D. R., McCants, R. L., Yellon, S. M., Wilkinson, C. W., Matsumoto, A. M., Rasmussen, D. D. (2000). Daily melatonin administration to middle-aged male rats suppresses body weight, intraabdominal adiposity, and plasma leptin and insulin independent of food intake and body fat. Endocrinology. 141:487-497.

Zemkova, H. and Vanecek, J. (1997). Inhibitory effect of melatonin on gonadotrpin-releasing hormone-induced $\mathrm{Ca}^{2+}$ oscillations in pituitary cells of newborn rats. Neuroendocrinology. 165:276-283. 